\title{
INVESTIGATION OF THE IMPACT OF SEISMIC ZONE TO THE COST OF CONSTRUCTION OF A 5-STOREY R/C BUILDING
}

\author{
Theodoros A. Chrysanidis ${ }^{1}$, Nikolaos O. Alamanis ${ }^{2}$, Grigorios P. Papageorgiou ${ }^{3}$, Geor- \\ gia Kaouri ${ }^{1}$
}

\author{
${ }^{1}$ Hellenic Open University \\ Parodos Aristotelous 18, P.C. 26335, Patra, Greece \\ theodoros_gr@yahoo.com \\ ${ }^{2}$ University of Thessaly \\ P.C. 41110, Larissa, Greece \\ alam@teilar.gr \\ ${ }^{3}$ University of Thessaly \\ V. Griva 11, P.C. 41300, Karditsa, Greece \\ gpapageor@uth.gr
}

\begin{abstract}
Residing in a country like Greece, where the earthquake is a common phenomenon in most of its areas, the need for constructing earthquake resistant buildings that will provide security and functionality to their residents is imperative. For this reason, the present study estimates the cost of constructing the same five-storey building in three different seismic hazard zones. Initially, this building is studied, in accordance with the provisions of Eurocode 8, for seismic zones I, II and III. The dimensioning and calculation of the weight of the required steel and the volume of the required concrete is carried out. The results from the three seismic zones are presented in detail, both for each structural element of the construction separately and for the whole construction, and a comparison is made between them.
\end{abstract}

Keywords: Seismic hazard zones, Multi-storey building, Construction's cost, Reinforcement 


\section{INTRODUCTION}

In modern times, various materials are used for the construction of high-rise buildings. The choice of these materials can be made depending on the use of the building, the area in which it is located, the architectural and static study, the cost of construction [1]-[5]. However, in Greece, for the majority of buildings, reinforced concrete is used as a construction material. A reinforced concrete building is made of concrete and steels in the form of rebars or ties. These two materials are harmoniously combined in order, on the one hand, the concrete to receive the compressive forces and on the other hand, the steel to receive the tensile stresses [6], [7]. Greece is an intensely seismic country and as earthquake action is a dangerous and destructive natural phenomenon, the buildings, whether they are new constructions or older, must deal with it effectively. This effective response comes through the design and construction of antiseismic buildings, but also the strengthening of existing ones [8]-[18].

Nowadays, more and more high-rise buildings are being constructed, with many floors, which are quite sensitive, not only to large earthquakes, but also to less intense ones, if they are not built properly. One of the main problems of these buildings is that, during the earthquake, probably some of their floors move in one direction, while at the same time the other floors move in the opposite direction [19], [20]. Therefore, the engineer should take very seriously the seismic zone in which each building is constructed. The seismic zone significantly affects the dimensioning of the structure, the cross sections of its structural elements and their reinforcement, thus affecting its cost. The engineer has the ability, if for some reason he deems it necessary, to dimension his building in a higher seismic zone than the one to which the building belongs. However, he should not forget that his choice will increase the final construction cost.

The present study presents the simulation and dimensioning, based on modern regulations, of three buildings which have the same standard floor plan, the number of floors (five floors), but are located in different seismic zones. The cost comparisons for the same building between the three different seismic zones leads to useful and interesting conclusions.

\section{ANALYTICAL RESEARCH}

\subsection{Construction description}

The floor plan of the building has dimensions $25 \times 25 \mathrm{~m}$, therefore the total area of the floor plan is equal to $E=625.00 \mathrm{~m}^{2}$ (Figure 1). The height of the floors is $\mathrm{h}=3.00 \mathrm{~m}$, except for the height of the first floor (ground floor) which is $\mathrm{h}=4.50 \mathrm{~m}$. Therefore, the total height of the building is $h_{\text {tot }}=16.5 \mathrm{~m}$. Rigid supports are used and the effect of soil is neglected [21], [22].

The main element of the load-bearing structure can be characterized as the main core, which is located in the center of the building and includes the elevators and stairwells. Regarding the dimensions of the structural elements, there are some small differences from floor to floor. There are also some structural walls in the building. These are the structural walls $\mathrm{T}_{3}$ and $\mathrm{T}_{10}$ at the two sides of the building's plan. Finally, in terms of beams, they are divided into perimeter and internal. The dimensions of the perimetric beams and the beams of the core are $25 \times 70 \mathrm{~cm}$ and the internal ones have dimensions $25 \times 60 \mathrm{~cm}$. The cross-sections of the structural elements are shown in Table 1. 


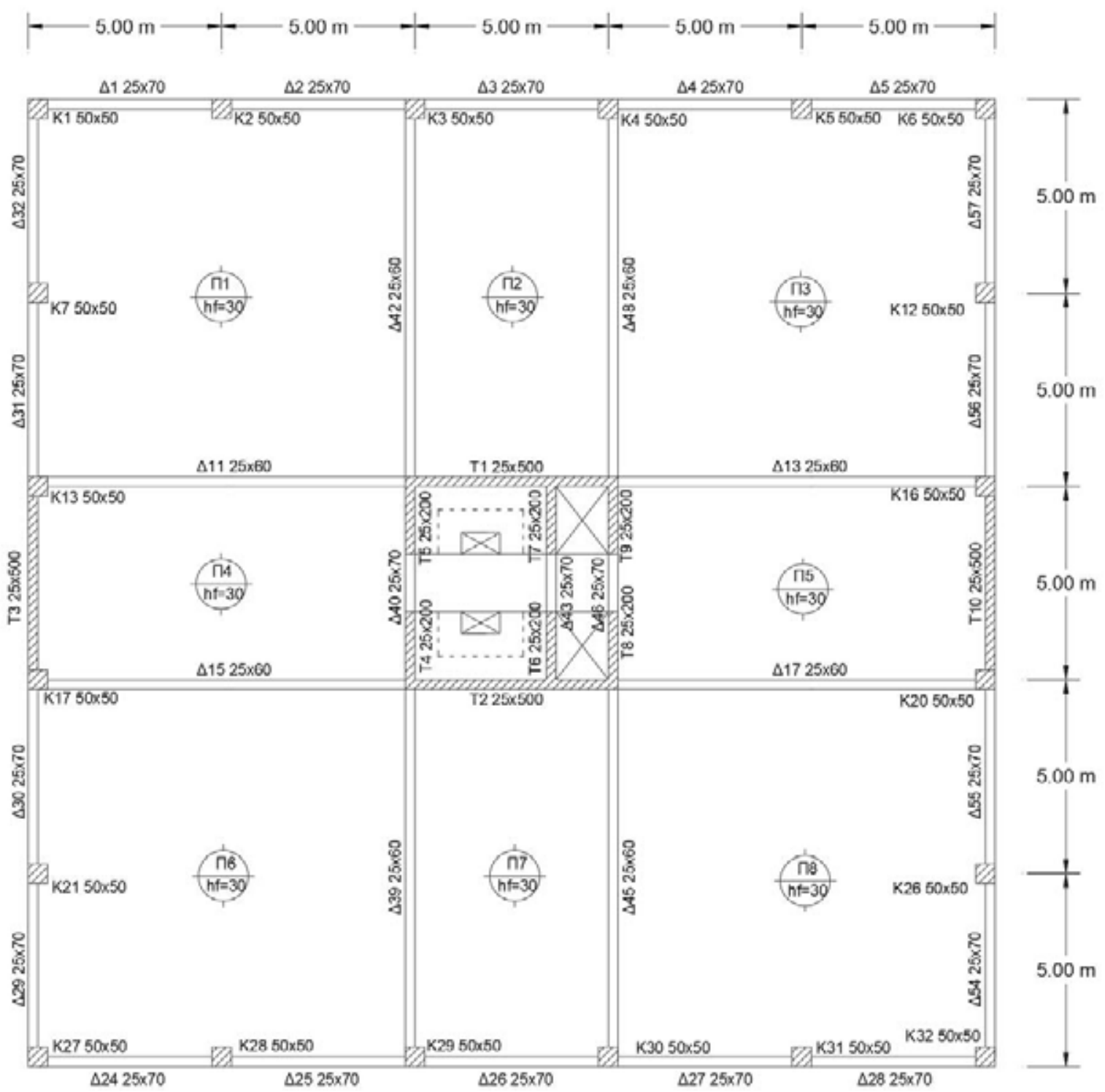

Figure 1: Typical floor plan.

\begin{tabular}{|c|c|c|c|c|c|}
\hline \multirow{2}{*}{ Floor } & \multirow{2}{*}{$\begin{array}{c}\text { Height } \\
(\mathbf{m})\end{array}$} & \multicolumn{2}{|c|}{ Beam dimensions (cm) } & \multirow{2}{*}{$\begin{array}{c}\text { Wall thickness } \\
(\mathbf{c m})\end{array}$} & $\begin{array}{c}\text { Column dimensions } \\
(\mathbf{c m})\end{array}$ \\
\cline { 3 - 4 } & & Perimetric & Internal & & \\
\hline $\mathbf{1}^{\text {st }}$ (Ground floor) & 4.50 & $25 \times 70$ & $25 \times 60$ & 25 & $50 \times 50$ \\
\hline $\mathbf{2}$ & 3.00 & $25 \times 70$ & $25 \times 60$ & 25 & $50 \times 50$ \\
\hline $\mathbf{3}$ & 3.00 & $25 \times 70$ & $25 \times 60$ & 25 & $45 \times 45$ \\
\hline $\mathbf{4}$ & 3.00 & $25 \times 70$ & $25 \times 60$ & 25 & $40 \times 40$ \\
\hline $\mathbf{5}$ & 3.00 & $25 \times 70$ & $25 \times 60$ & 25 & $35 \times 35$ \\
\hline
\end{tabular}

Table 1: Dimensions of the structural elements. 


\subsection{Materials}

For all the load-bearing structural elements of the construction, concrete quality $\mathrm{C} 30 / 37$ and steel quality B500C were used for the reinforcement bars. According to Eurocode 2 [23], for concrete quality $\mathrm{C} 30 / 37$, the modulus of elasticity is given equal to $\mathrm{E}_{\mathrm{cm}}=32 \mathrm{GPa}$. The Poisson ratio is considered equal to zero $(v=0)$ for cracked. The steel quality B500C has a characteristic strength equal to $\mathrm{f}_{\mathrm{yk}}=500 \mathrm{MPa}$.

\subsection{Analysis method}

The building was analyzed for the vertical loads applied under the combination of $1.35 \mathrm{G}+$ $1.50 \mathrm{Q}$, as well as for the seismic actions under the combination of $\mathrm{G}+\psi_{2} \mathrm{Q} \pm \mathrm{E}$. The dynamic spectral method was used for the dynamic analysis of the building. The building was analyzed and examined in three different seismic hazard zones. In zone I with maximum seismic horizontal ground acceleration $\mathrm{ag}_{\mathrm{g}}=0.16 \mathrm{~g}$, in zone II with $\mathrm{a}_{\mathrm{g}}=0.24 \mathrm{~g}$ and in zone III with $\mathrm{a}_{\mathrm{g}}=$ $0.36 \mathrm{~g}$ (where $\mathrm{g}$ is the acceleration of gravity and is equal to $9.81 \mathrm{~m} / \mathrm{sec}^{2}$ ). Also, the design spectrum was used, according to Eurocode 8 [24], for soil category B and spectrum type 1. Spectrum data used according to EC8 are displayed in Table 2:

\begin{tabular}{|c|c|c|}
\hline \multicolumn{2}{|c|}{ SPECTRUM DATA EC8 } \\
\hline N/A & Type & Data \\
\hline $\mathbf{1}$ & Spectrum type & Borizontal design spectrum type 1 \\
\hline $\mathbf{2}$ & Soil category & 0.20 \\
\hline $\mathbf{3}$ & Factor $\beta$ & For the three categories: $\alpha=0.16,0.24,0.36$ \\
\hline $\mathbf{4}$ & Seismic acceleration factor $\alpha$ & $9.81 \mathrm{~m} / \mathrm{sec}^{2}$ \\
\hline $\mathbf{5}$ & Gravity acceleration $\mathrm{g}$ & Calculation based on EC8 \\
\hline $\mathbf{6}$ & Coefficient behavior $\mathrm{q}$ & \\
\hline
\end{tabular}

Table 2: Spectrum data used for the dynamic analysis.

\subsection{Gravity loads}

The weight of the reinforced concrete is considered equal to $25.00 \mathrm{kN} / \mathrm{m}^{3}$. The load of the partition masonry is considered to be evenly distributed over the entire surface of the floor plan and the load of the perimeter masonry is applied only on the perimeter beams and directly on them. Also, on the roof, all around the perimeter is considered to be a parapet with a height equal to $0.90 \mathrm{~m}$. Flooring is considered to be equal to $1.40 \mathrm{kN} / \mathrm{m}^{2}$. The permanent load for the masonry structures is taken equal to $1.00 \mathrm{kN} / \mathrm{m}^{2}$ for the internal brick structures used as partitions and equal to $8.00 \mathrm{kN} / \mathrm{m}$ for the masonry structures at the perimeter of the slab of the building. The roofing is considered equal to $3.50 \mathrm{kN} / \mathrm{m}^{2}$ and the load for the parapet which is at the perimeter of the roof is assumed as equal to $3.60 \mathrm{kN} / \mathrm{m}^{2}$. Live loads are considered equal to $2.00 \mathrm{kN} / \mathrm{m}^{2}$ at every floor slab; meaning for the ground floor, the other typical floors and the roof. Permanent and live loads are shown at Table 3. 
Theodoros A. Chrysanidis, Nikolaos O. Alamanis, Grigorios P. Papageorgiou, Georgia Kaouri

\begin{tabular}{|c|c|c|}
\hline \multicolumn{3}{|c|}{ PERMANENT LOADS } \\
\hline N/A & Type & Value \\
\hline $\mathbf{1}$ & Flooring & $1.40 \mathrm{kN} / \mathrm{m}^{2}$ \\
\hline $\mathbf{2}$ & Partition brick structures & $1.00 \mathrm{kN} / \mathrm{m}^{2}$ \\
\hline $\mathbf{3}$ & Perimeter brick structures & $8.00 \mathrm{kN} / \mathrm{m}$ \\
\hline $\mathbf{4}$ & Roofing & $3.50 \mathrm{kN} / \mathrm{m}^{2}$ \\
\hline $\mathbf{5}$ & Parapet roof load & $3.60 \mathrm{kN} / \mathrm{m}^{2}$ \\
\hline \multicolumn{2}{|c|}{ LIVE LOADS } \\
\hline N/A & Type & Value \\
\hline $\mathbf{1}$ & Ground floor & $2.00 \mathrm{kN} / \mathrm{m}^{2}$ \\
\hline $\mathbf{2}$ & Typical floors & $2.00 \mathrm{kN} / \mathrm{m}^{2}$ \\
\hline $\mathbf{3}$ & Roof & $2.00 \mathrm{kN} / \mathrm{m}^{2}$ \\
\hline
\end{tabular}

Table 3: Permanent and live loads.

\subsection{Modelling and dimensioning}

Some assumptions were used in the design of the model of the five-storey building. Stiffness for cracked sections is considered equal to 0.5 . Torsional stiffness is considered equal to 0.1. For the calculation of the masses of each floor, half the masses of the vertical structural elements of the underneath floor and half the masses of the vertical structural elements of the upper floor were used. In the context of this study, the dimensioning of the individual structural elements was carried out exclusively for the first floor (ground floor) of the five-storey building, for each of the three seismic zones. Figure 2 shows the 3D model of the building. Figure 3 displays the methodology with which the slab loads are transferred to the beams.

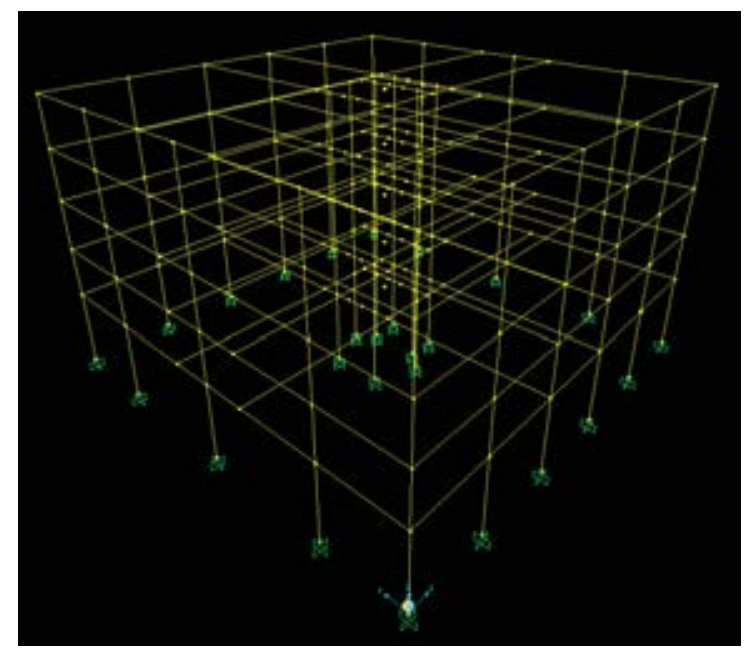

(a)

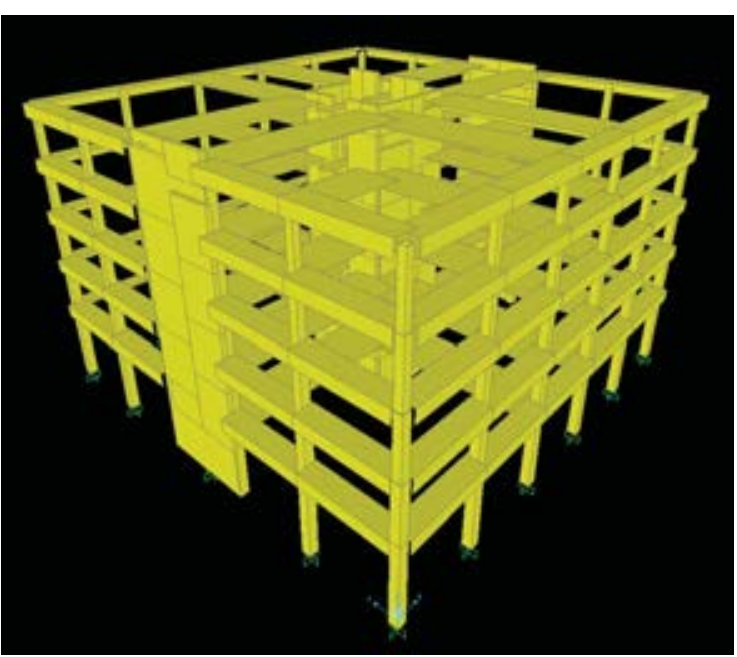

(b)

Figure 2: Views of the 3D building model: (a) Linear finite elements (b) Sections. 


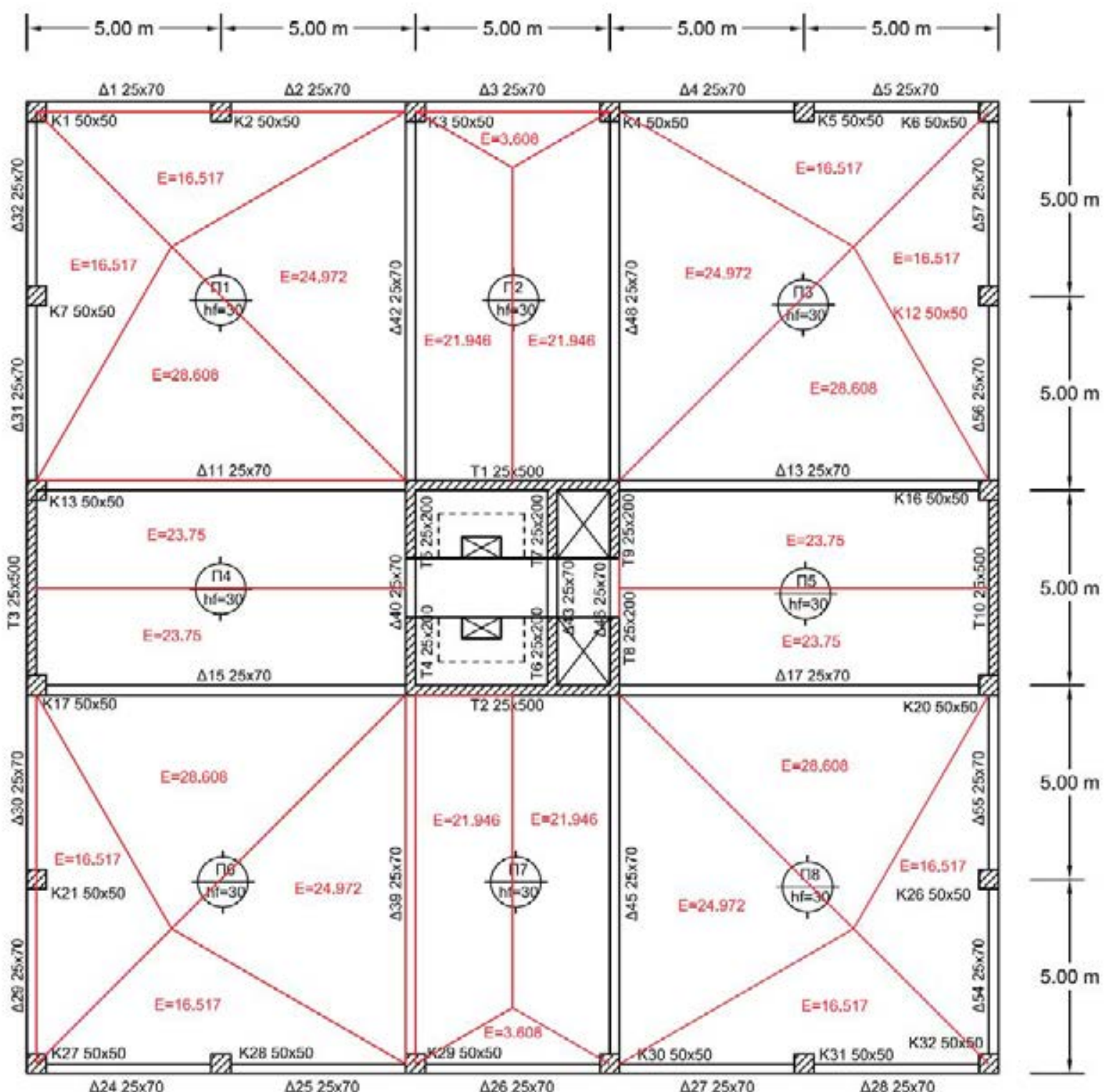

Figure 3: Methodology of calculating beam loads.

\section{MEASUREMENTS OF MATERIALS}

\subsection{Concrete and steel measurements for the ground floor}

Concrete and steel used for the reinforcement of the structural elements are measured for the ground floor. Concrete is measured in terms of volume and reinforcement steel is measured in terms of weight. Table 4 displays the amount of concrete occupied by the structural elements of the load-bearing structure for all three seismic zones. Also, the same table displays the weight of steel used for all three seismic zones, too. Furthermore, the steel over concrete ratio is calculated and the increase of the steel weight is given in terms of percentages, again for all three seismic hazard zones. 


\begin{tabular}{|c|c|c|c|c|c|}
\hline \multicolumn{6}{|c|}{ GROUND FLOOR } \\
\hline Seismic zone & $\begin{array}{c}\text { Concrete volume } \\
\qquad\left(\mathbf{m}^{3}\right)\end{array}$ & $\begin{array}{c}\text { Steel weight } \\
(\mathrm{kg})\end{array}$ & $\begin{array}{c}\text { Steel / concrete } \\
\text { ratio } \\
\left(\mathrm{kg} / \mathrm{m}^{3}\right)\end{array}$ & \multicolumn{2}{|c|}{$\begin{array}{c}\text { Increase of steel } \\
\text { weight } \\
(\%)\end{array}$} \\
\hline Zone I & 248.325 & 19721.91 & 79.42 & \multicolumn{2}{|c|}{-} \\
\hline Zone II & 248.325 & 21202.56 & 85.38 & \multicolumn{2}{|c|}{7.51} \\
\hline Zone III & 248.325 & 22360.64 & 90.05 & 13.38 & 5.46 \\
\hline
\end{tabular}

Table 4: Concrete and steel measurements for ground floor.

\subsection{Concrete and steel measurements for the whole building}

The measurements of the materials calculated for the ground floor are used for the estimation of the quantities of the concrete and steel needed for the whole load-bearing structure of the building. Table 5 shows the results for the quantities of concrete and steel for the whole building structure.

\begin{tabular}{|c|c|c|c|c|c|}
\hline \multicolumn{6}{|c|}{ BUILDING } \\
\hline Seismic zone & $\begin{array}{c}\text { Concrete volume } \\
\qquad\left(\mathbf{m}^{3}\right)\end{array}$ & $\begin{array}{c}\text { Steel weight } \\
(\mathrm{kg})\end{array}$ & $\begin{array}{c}\text { Steel / concrete } \\
\text { ratio } \\
\left(\mathrm{kg} / \mathrm{m}^{3}\right)\end{array}$ & \multicolumn{2}{|c|}{$\begin{array}{c}\text { Increase of steel } \\
\text { weight } \\
(\%)\end{array}$} \\
\hline Zone I & 1151.58 & 93636.64 & 81.31 & \multicolumn{2}{|c|}{ - } \\
\hline Zone II & 1151.58 & 99738.59 & 86.61 & \multicolumn{2}{|c|}{6.52} \\
\hline Zone III & 1151.58 & 105118.39 & 91.28 & 12.26 & 5.39 \\
\hline
\end{tabular}

Table 5: Concrete and steel measurements for building.

\section{ANALYSIS OF RESULTS}

\subsection{Concrete and steel measurements for the ground floor}

The ratio of reinforcement steel used for the rebars over the concrete volume used for concreting the structural elements of the load-bearing structure is calculated for all three seismic hazard zones both for ground floor and for the whole building (Figure 4). Moreover, the reinforcement steel weight increment when changing seismic zone is calculated, too. This calculation takes place for changing from zone I to zone II, from zone I to zone III and from zone II to zone III both for the ground floor, as well as, for the whole building (Figure 5). 


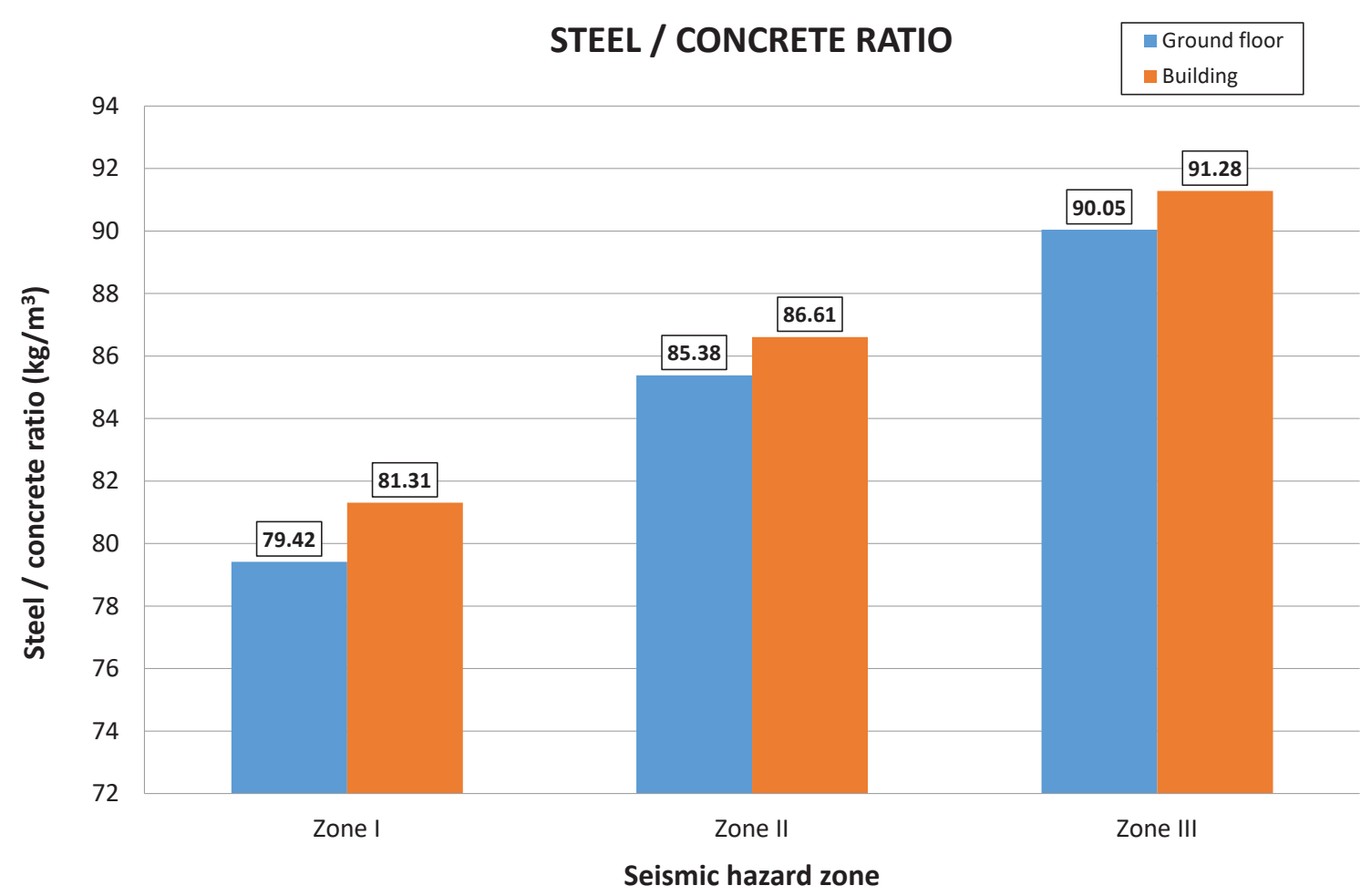

Figure 4: Steel / concrete ratio diagram for the ground floor and the whole building.

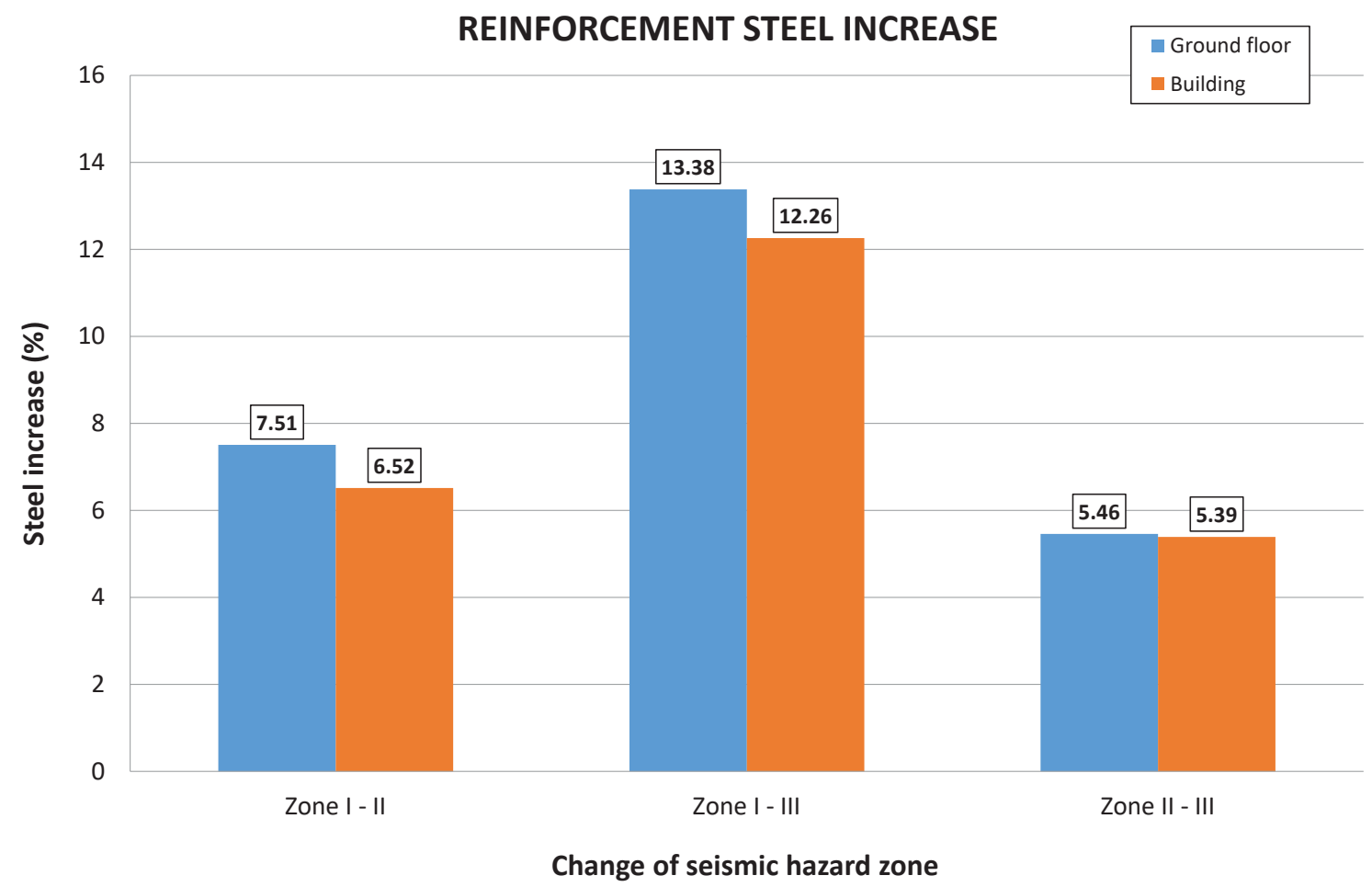

Figure 5: Diagram of steel increase when changing seismic zone for the ground floor and the whole building. 


\subsection{Analysis of results}

The analysis of the previous results leads to the following:

1. As far as the floor slabs are concerned, both the volume of their concrete and the weight of their steel do not change in the three seismic hazard zones.

2. Collectively, in terms of reinforcement steel weight, there is an increase of $6.52 \%$ from seismic zone I to II and 5.39\% from seismic zone II to III (Figure 5). The increase rates of the steel weight for the ground floor of the building are similar, $7.51 \%$ and $5.46 \%$ respectively (Figure 5).

3. Also, Table 5 and Figure 4 show that the requirement of the five-storey building in reinforcement in seismic zone I is 94 tn with steel to concrete ratio equal to $81.31 \mathrm{~kg} / \mathrm{m}^{3}$, while for zone III the weight of reinforcement reaches 105 tn with a ratio of steel to concrete equal to $91.28 \mathrm{~kg} / \mathrm{m}^{3}$.

\section{CONCLUSIONS}

The observation of the measurement tables of the concrete volume and those of the steel weight of the various structural elements of the building in question, as well as the tables and the various diagrams concerning the steel/concrete ratio and the percentage increase of the weight of steel leads to some conclusions that mainly concern the behavior of the structural elements but also the whole construction in the three seismic hazard zones and consequently the cost that will be spent for this construction.

1. From seismic zone I to zone II, there is an increase in seismic acceleration of $50 \%$, from I to III $125 \%$ and from II to III $50 \%$. These percentages should be compared mainly with the percentages of increase in the weight of steel, in order to prove if the construction cost of the building is within reasonable limits.

2. The sizing of the slabs, whether it concerns the reinforcement (steel weight) or the cross sections (volume of concrete) remains constant in all three seismic zones. Therefore, the ratio of steel to concrete in the slabs also remains constant for all floors and finally throughout the construction.

3. Regarding the whole construction, as it is logical, as the weight of the reinforcement increases separately for each structural element, moving from one seismic zone to another, the same increases for the whole construction. This change plays a very important role, as with the increase of the weight of the reinforcement, there is a corresponding increase of the cost of the structure. However, the total increase in the quantity of materials and consequently the construction cost from seismic zone I to II is only of the order of $6.52 \%$, i.e., 8 times less than the increase in seismic acceleration in the respective zones. Also, the increase in the amount of materials from seismic zone I to III is of the order of $12.26 \%$, i.e., 10 times less than the increase in seismic acceleration in these zones. Finally, the increase in the amount of materials from seismic zone II to III is of the order of 5.39\%, i.e., 9 times smaller than the increase in seismic acceleration in the respective zones.

4. In conclusion, observing the results obtained for all the structural elements in the three seismic zones, it can be said that the rate of increase of construction costs from one zone to another is quite small in relation to the rate of increase of seismic acceleration in the respective seismic hazard zones. Thus, if the engineer wishes, for reasons of greater safety, to dimension a construction, using the immediately larger seismic zone than the one in which the construction is actually located, he can do so without significantly increasing the cost of materials $(6.52 \%$ from seismic zone I to II and $5.39 \%$ from seismic zone II to III). The same could be said for the case where the building is 
located in the seismic hazard zone I and the engineer wishes to dimension it in zone III. The rate of increase of the cost of materials (12.26\%) is less than the safety that thus ensures the engineer for the relevant structure.

\section{REFERENCES}

[1] T. Chrysanidis and I. Tegos, "Cost Comparison and Parametrical Investigation of the R/C Shear Wall Core of a Tall Building," International Journal of Engineering Research and Technology, vol. 5, no. 09, pp. 592-595, 2016.

[2] T. Chrysanidis, V. Panoskaltsis, and I. Tegos, "Parametrical cost analysis of an ultra high-rise building: Detailed design," International Journal of Applied Engineering Research, vol. 11, no. 18, pp. 9644-9650, 2016.

[3] G. Papageorgiou, E. Papadimitriou, N. Alamanis, N. Xafoulis, I. Chouliaras, and K. Lazogiannis, "Construction cost comparative analysis of highways in Greece," PRIME International Journal Practical Research in Innovative Management \& Entrepreneurship, vol. 12, no. 1, pp. 68-85, 2019.

[4] G. Papageorgiou, "Economic assessment of pavement maintenance and strengthening techniques in view of implementation cost," European Transport, no. 78, p. Article 5, 2020.

[5] A. Tsiknas, A. Athanasopoulou, and G. Papageorgiou, "Evaluation of flexible pavement construction cost according to the design method," Proceedings of the Institution of Civil Engineers (ICE) - Transport, vol. 173, no. 1, pp. 3-12, 2020.

[6] G. G. Penelis and A. J. Kappos, Earthquake-resistant Concrete Structures. London, UK: E \& F N SPON (Chapman \& Hall), 1996.

[7] G. Penelis, K. Stylianidis, A. Kappos, and C. Ignatakis, Reinforced Concrete Structures. Thessaloniki, Greece: A.U.Th. Press, 1995.

[8] T. Chrysanidis, "Evaluation of Out-of-Plane Response of R/C Structural Wall Boundary Edges Detailed with Maximum Code-Prescribed Longitudinal

Reinforcement Ratio," International Journal of Concrete Structures and Materials, vol. 14, no. 1. 2020, doi: 10.1186/s40069-019-0378-4.

[9] T. Chrysanidis and I. Tegos, "Axial and transverse strengthening of R/C circular columns: Conventional and new type of steel and hybrid jackets using high-strength mortar," Journal of Building Engineering, vol. 30, no. January, p. 101236, 2020, doi: 10.1016/j.jobe.2020.101236.

[10] S. Raza, M. Khan, S. Menegon, H.-H. Tsang, and J. Wilson, "Strengthening and repair of reinforced concrete columns by jacketing: State-of-the-art review," Sustainability (Switzerland), vol. 11, no. 11, pp. 1-31, 2019, doi: 10.3390/su11113208.

[11] T. Chrysanidis, "Influence of elongation degree on transverse buckling of confined boundary regions of R/C seismic walls," Construction and Building Materials, vol. 211, pp. 703-720, Jun. 2019, doi: 10.1016/J.CONBUILDMAT.2019.03.271.

[12] I. Tegos, N. Giannakas, and T. Chrysanidis, "Cross-correlation of stresses in the transverse reinforcement under shear load and confinement," in Proceedings of the 2013 International Van Earthquake Symposium, 2013. 
[13] I. Tegos, T. Chrysanidis, and M. Tsitotas, "Seismic behaviour of R/C columns and beams with interlocking spirals," International Journal of Scientific and Engineering Research, vol. 5, no. 8, pp. 310-319, 2014.

[14] I. Tegos and T. Chrysanidis, "Spare Additional Confinement in Spiral Arrangements," International Journal of Scientific Research, vol. 3, no. 9, pp. 110-113, 2014.

[15] I. Tegos and T. Chrysanidis, "Columns With Spiral Reinforcement Under Concentric Compression," International Journal of Research in Engineering and Technology, vol. 03, no. 08, pp. 125-132, 2014, doi: 10.15623/ijret.2014.0308020.

[16] G. Minafò and M. Papia, "Concrete softening effects on the axial capacity of RC jacketed circular columns," Engineering Structures, vol. 128, pp. 215-224, 2016, doi: 10.1016/j.engstruct.2016.09.043.

[17] G. Minafò, "A practical approach for the strength evaluation of RC columns reinforced with RC jackets," Engineering Structures, vol. 85, pp. 162-169, 2015, doi: 10.1016/j.engstruct.2014.12.025.

[18] A. Takeuti, J. de Hanai, and A. Mirmiran, "Preloaded RC columns strengthened with high-strength concrete jackets under uniaxial compression," Materials and Structures, vol. 41, no. 7, pp. 1251-1262, 2008, doi: 10.1617/s11527-007-9323-0.

[19] S. Taghavi and E. Miranda, "Approximate Floor Acceleration Demands in Multistory Buildings. II: Applications," Journal of Structural Engineering, vol. 131, no. 2, pp. 212-220, 2005, doi: 10.1061/(asce)0733-9445(2005)131:2(212).

[20] S. Otani, T. Kabeyasawa, H. Shlohara, and H. Aoyama, "Analysis of the full scale seven story reinforced concrete test structure," Symposium Paper, vol. 84, no., pp. 203-239, 1984.

[21] N. Alamanis and P. Dakoulas, "Investigation on the effect of spatial variability of soil properties on permanent seismic displacements of slopes in load," in 14th Baltic Sea Geotechnical Conference 2020, 2020.

[22] N. Alamanis and P. Dakoulas, "Vulnerability of soil slopes against seismic damage based on the effect of spatial variability of soil properties on the development of permanent seismic displacements," in International Conference on Research in Engineering, Technology and Science, 2019.

[23] European Committee for Standardization, "EN 1992-1-1:2004, Eurocode 2: Design of concrete structures - Part 1-1: General rules and rules for buildings," Brussels, Belgium, 2004.

[24] European Committee for Standardization, "EN 1998-1:2004, Eurocode 8: Design of structures for earthquake resistance - Part 1: General rules, seismic actions and rules for buildings," Brussels, Belgium, 2004. 